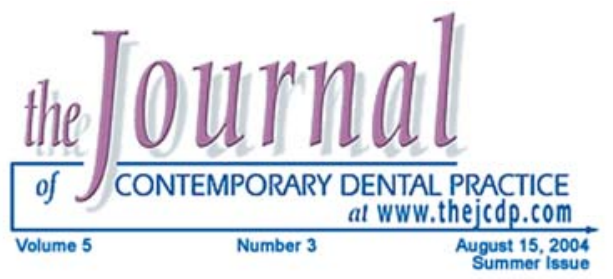

\title{
The Epidemiology, Etiology, and Pathophysiology of Acute Necrotizing Ulcerative Gingivitis Associated with Malnutrition
}

\section{M.O. Folayan, BChD, MBA, FWACS}

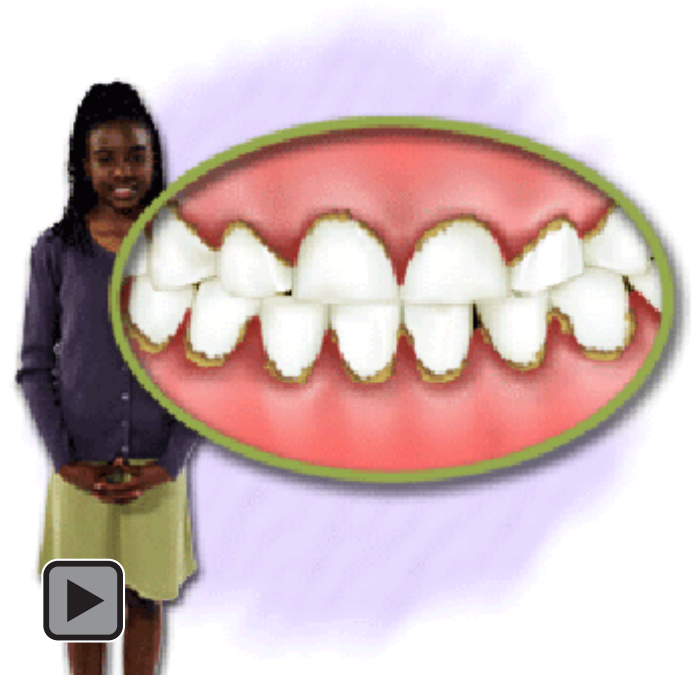

Abstract

Acute Necrotizing Ulcerative Gingitivitis (ANUG) is a distinct and specific disease. This disease entity has been described as far back as the days of Hippocrates and is known by many synonyms. With the advent of antibiotics and with improved nutritional status, the incidence has decreased and even become extinct in developed countries. However, with the increasing incidence of severe immunodeficiency states such as seen in Acquired Immunodeficiency Syndrome (AIDS) the lesion has once more, become a well recognized and often encountered clinical entity in developed countries. In developing countries, however, the condition is still a commonly diagnosed clinical lesion because of the persistently poor nutritional status. Because of the current campaign for increased focus on global health issues, ANUG, a lesion of significant interest for the developing countries where malnutrition is high and for developing countries because of the AIDS, a global pandemic has resurfaced as a topic for discussions and study. This literature review will provide a better understanding of the epidemiology, etiology, and pathophysiology of ANUG associated with malnutrition.

Keywords: Acute Necrotizing Ulcerative Gingivitis, ANUG, epidemiology, etiology, pathophysiology

Citation: Folayan MO. The Epidemiology, Etiology, and Pathophysiology of Acute Necrotizing Ulcerative Gingivitis Associated with Malnutrition. J Contemp Dent Pract 2004 August;(5)3:028-041.

(C) Seer Publishing 
Introduction

Acute Necrotizing

Ulcerative Gingitivitis

(ANUG), now clas-

sified as Necrotizing

Periodontal Disease

according to the 1999

American Academy of Periodontics classification system, is a distinct and specific disease characterized by rapidly progressive ulceration typically starting at the tip of the interdental papilla, spreading along the gingival margins, and going on to acute destruction of the periodontal tissue.

This disease entity has been described as far back as the days of Hippocrates and is known by many synonyms such as trench mouth, Vincent's disease, and Vincent's gingivostomatitis. A rapid progression of the lesion can lead to cancrum oris $^{1,2}$ which, in turn, is very disfiguring and potentially fatal. With the advent of antibiotics and with improved nutritional status, the incidence has decreased and even become extinct in developed countries. Although, with the increasing incidence of severe immunodeficiency states such as seen in Acquired Immunodeficiency Syndrome (AIDS) the lesion has once more, become a well recognized and often encountered clinical entity in developed countries. $^{3}$

In developing countries ANUG remains a commonly diagnosed clinical lesion. This is because of the existing poor nutritional status, stressful living conditions, poor oral hygiene, and a state of debilitation often resulting from endemic contagious diseases. ${ }^{1,4-6}$

This lesion is important in the light of the severe irreversible disabilities that results when its progression is unchecked. The highlighted risk factors are highly controllable, especially where the issue of malnutrition is concerned. In developing nations where the standard of living is gradually on the decline, this disfiguring oral lesion becomes very important clinically as more and more children are exposed to the risk factors which lead to the development of ANUG.

In recent years, there has been increasing recognition for the need to further study ANUG, particularly in view of its contribution to the incidence of cancrum oris - which has been described as a "neglected third world disease" and a "neglected scourge" of children in Sub-Saharan Africa. ${ }^{1,7}$ The increasing focus on global health issues has made ANUG a lesion of significant interest for developing countries where malnutrition is high and because of HIV/AIDS, a global pandemic.

\section{Epidemiology}

ANUG was well known in Europe and North America some centuries ago. These Western Countries reported ANUG especially among military personnel. As far back as 401BC, Xenophon $^{8}$ described a clinical entity similar to ANUG in the mouths of his soldiers. Bergeron ${ }^{9}$ in 1859 also described a similar disease entity amongst French troops he served with. The few cases reported in the literature in Europe and North America before its association with AIDS was usually among military personnel. ${ }^{10-12}$

However, with the HIV infection so widespread, ANUG has become widely recognized as a lesion which is strongly pathognomonic of the infection, especially when seen in healthy looking young adults. ${ }^{13,14}$ Reports of the prevalence of ANUG among HIV infected patients vary between $4.3 \%$ to $16.0 \%$. $^{14-16}$

In marked contrast, the disease is still frequently seen in developing countries, especially in SubSaharan Africa where it occurs almost exclusively among poor children usually between the ages of 3 years and 10 years from low socio-economic backgrounds. ${ }^{1,4,13,17-20}$ Similar observations have also been reported in India. ${ }^{22}$ In Nigeria, hospital based studies within the past decade suggest the incidence of ANUG is increasing among children with a prevalence as high as $23 \%$ in children under 10 years of age having been reported. ${ }^{1,19,20}$

This probable high association of ANUG with kids in Sub-Saharan Africa may have to do with poor welfare programs for children in these countries as the health the child is not given any priority. These children, therefore, become exposed to identified risk factors which predisposes them to ANUG.

\section{Etiology and Pathophysiology}

\section{Microbiology}

The precise etiology of ANUG is not known, however, it is believed to be a polymicrobial infection with the implicated organisms being normal 
commensals of the oral cavity. However, when the local resistance of the human gingival area becomes reduced, the organisms then become pathogenic. $^{4}$

Vincent and Plaut were the first to recognize the fusiform-spirochete nature of ANUG. ${ }^{22}$ They recognized the fusiform-spirochete nature of this disease in 1890. Vincent identified Borrelia vincentii (a spirochete) and Bacillus vincentii (a fusiform) microscopically as pathognomonic of the lesion. This led to the lesion been formerly known widely as Vincent's disease. ${ }^{23}$ This evidence of the fusiform-spirochete component of the disease was reinforced by other light microscopic evidence ${ }^{24-26}$ and later through electron microscopic evaluation. ${ }^{27}$ However, the significant role of these organisms became doubtful as these bacterial forms were present without exception in other oral inflammatory lesions as well as in the oral cavity of periodontally healthy individuals. Their ubiquitous occurrence, therefore, disqualified them as organisms of importance in the diagnosis of ANUG. The exact role of these fusiform and spirochete microbes was also complicated by reports from MacDonald et al. ${ }^{28}$, who found that spirochetes and fusiform were non essential in the production of the infections in guinea pigs but later found Bacteroides melaninogenicus as the essential pathogen in their inoculation mixture. ${ }^{29}$

Hampp and Mergenhagen ${ }^{30}$ also found the small treponemas, $B$. vincentii, and $B$. bucalis were capable of producing localized infections and abscess formations in the skins of rabbits and guinea pigs. They, therefore, suggested that ANUG was a complex mixed infection involving at least four organisms.

More light was shed on the bacterial nature of ANUG by Loesche et al. ${ }^{31}$ when they did quantitative cultures of plaque samples from ANUG sites under anaerobic conditions. A partial characteristic of the microbial analysis was done, and they determined the cultivated flora contained a "constant portion" and a "variable portion." The constant portion contains a limited number of bacterial types which is believed to be pathogenic for ANUG. These include Treponema species and the spirilla - like selenomonas species. The variable portion of the flora contained a heterogenous array of various bacterial types. Loesche believes this association of the bacteroides species with ANUG is particularly significant, especially when experimental metronidazole treatment caused a prompt resolution of the clinical symptoms which coincided with a significant reduction of the Treponema species, B. melaninogenicus spp intermedius, and fusobacterium.

Earlier research by Chung et al. ${ }^{32}$ who reported significantly higher $\lg G$ and $\lg M$ antibody titre to intermediate sized spirochetes and higher IgG titre to $B$. melaninogenicus spp. intermedius in ANUG patients when compared with age and sex matched healthy and gingivitis control groups supported Loesche's hypothesis. They stated these high antibody titre "suggest that these bacteria are pathologically significant agents and not merely secondary invaders of ANUG lesion." However, the Wilton et al. ${ }^{33}$ study found no differences in serum antibody levels to bacterial antigen including $B$. melaninogenicus in patients with ANUG when compared with controls. This result may, however, be due to the selection of different serotypes of bacteria for testing.

The main anaerobic organisms currently implicated in ANUG are fusobacterium necrophorum; Bacteroides meaningenicus spp. Intermedius, now known as Prevotella intermedia; Fusobacterum nucleatum; porphyromonas gingivalis as well as trepanoma and selemonas spps. ${ }^{7,34}$ These bacteroides species produce a wide range of destructive metabolites, e.g., collagenase, fibrinolysin, endotoxins, hydrogen sulfide, indole ammonia, fatty acids, protease capable of degrading immunoglobins, and complement factors as well as substances inhibiting neutrohpil chemotaxis. ${ }^{35,36}$

Fusobacterum necrophorum has been suggested to be the possible key micro-organism in causing ANUG to progress to cancrum oris. ${ }^{4,7,37}$ This is because its infectivity is markedly enhanced by the simultaneous presence of other bacteria ranging from strict aerobes to facultative and strict anaerobes such as Pseudomonas aeruginosa, $P$. intermedia, Bacteroides fragilis, and Staphylococcus aureus. ${ }^{38}$ In instances where cancrum oris like lesions have occurred in stressed, malnourished non-human primates (these are the same identified predisposing factos to ANUG), the key anaerobes isolated have been 


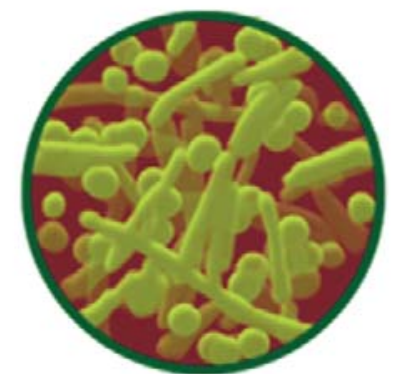

Fusobacterium necrophrom

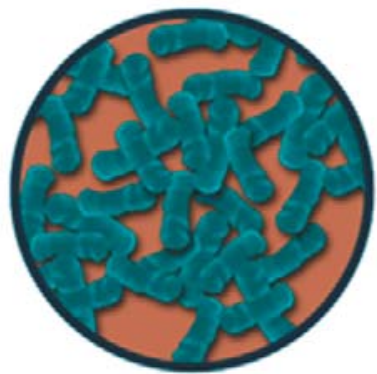

Prevotella intermedia

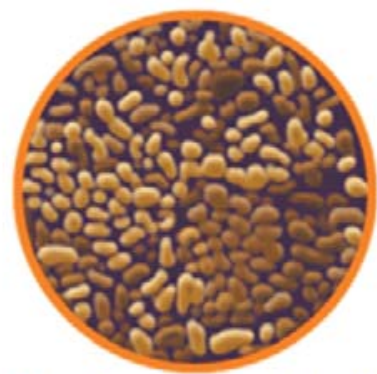

Porphyromonas gingivalis
Bacteroides spp. and Fusobacterium spp with $P$. aeruginosa and $S$. aureus as the predominant aerobes. $^{7,39}$

F. necrophonum occurs in human and animal fecal remains ${ }^{40}$ and has been cultured occasionally from periodontal lesions. ${ }^{41}$ It is also reported to play a key role in causing tropical ulcers, a painful tropical skin ulcer on the lower legs and feet of impoverished children in developing countries. ${ }^{42}$ This tropical ulcer has similarities with cancrum oris. $^{7}$ This organism, however, has little ability to invade epithelium and infection usually arises from the contamination of damaged mucosa or skin by fecal matter. ${ }^{38,40,43}$

\section{The Immune System}

Another aspect of the etiology of ANUG in association with malnutrition which has been investigated is the function of leucocytes and the role of the immune system. Cogen et al. ${ }^{44}$ reported a study in which the leucocyte function in ANUG patients was compared with that of controls matched for age, sex, race, and general plaque accumulation. The total leukocyte count for both control and ANUG patients were found to be the same, but the ANUG patients showed a marked depression of the polymorphonuclear leukocytes (PMN) responsiveness in both chemotaxis and phagocytosis when compared with the PMNs of the control. This is consistent with the findings of Courtois et al. ${ }^{27}$ who found a predominance of plasma cells and lymphocytes in some lesions rather than PMN. However, Listgaren's earlier study ${ }^{24}$ showed a predominance of PMNs in ANUG lesions. The Rowland et al. study ${ }^{45}$ on serum $1 \mathrm{gG}$ and $1 \mathrm{gM}$ level in ANUG patients also suggested impaired immune functions in these patients.

Further evidence to support alterations in immune function as an etiological factor in ANUG is the reported high incidence of ANUG in HIV positive patients. ${ }^{46}$ These patients have reduced numbers of the helper/induced T cell subset (T4) and an abnormal ratio of helper/inducer $t$ cells to suppressor cytotoxic $\mathrm{T}$ cells (T4/T8 ratio). Furthermore, ANUG is a prominent feature of AIDS patients with ANUG being 20.8 times

more likely to have CD4 counts less than 200 cells $/ \mathrm{mm}^{3}$.

\section{Malnutrition}

Enwonwu et $\mathrm{al}^{47}$ tried to explain the possible interrelationship between ANUG, protein-energy malnutrition, and immunological competence. Malnutrition impairs innate and adaptive defense mechanisms in the host with an associated dysfunction of the cytokine system. In addition, there are marked changes in the oral microbial ecology with a resultant preponderance of pathogenic organisms and an associated increase in the propensity of these bacteria to bind to the oral mucosa cells. ${ }^{47}$

Also, in protein energy malnutrition tissue integrity is markedly affected resulting in increased permeability of mucosa surfaces to oral microbes and their products. ${ }^{48}$ This is due to interference with normal cellular replacement arising from protein deficiency, which is highly needed for the fast rate of cell growth and cell turnover in human gingival mucosa and periodontal collagen fibres. $^{49-52}$ Studies in monkeys have demonstrated the synergism between oral microbial flora and malnutrition in the production of necrotizing ulcerative gingivitis. ${ }^{53}$ Malnutrition not only affects the structural and functional integrity of the tissues but also determines the character of their responses to pathogenic organisms. Also, the younger the individual, the more profound are the effects of malnutrition on tissue resistance. ${ }^{4}$

Furthermore, as a result of protein energy malnutrition, there is severe impairment of the normal endocrine balance. ${ }^{54}$ Adrenal hyperfunction is common especially in malnourished children. ${ }^{55}$ 
Plasma cortisol levels in these children have been found to be more than twice the level found in well-fed children of similar age. This is due to the reduction in the catabolic rate of the steroid with disorganization of the normal control mechanism so the synthesis rate remains high in the face of high circulating levels of plasma cortisol. ${ }^{56,57}$ Thus, acute febrile infections such as malaria, measles, and herpes simplex virus infection act as stressors that enhance adrenocortical secretion and further elevates the already increased plasma cortisol level in malnourished children ${ }^{58}$. This excessive cortisol produces a decrease in mitotic activity of epithelial tissue, while the reduced synthesis of collagen inhibits proliferation and migration of fibroblasts as well as diminishes the synthesis of connective tissue ground substance..$^{59-61}$ Also, the increased cortisol level results in the reduction in proliferative responsiveness of con A nitroge ${ }^{62}$. Con A nitrogen is important in the induction of proliferation of peripheral blood lymphocytes. Cortisol also suppresses the responsiveness of $B$ cells and the proportion of suppressor/cytotoxic $T$ cells (T8) in the peripheral blood increases ${ }^{62}$. Loesche $^{31}$ also suggested that the increased corticosteroid level might enhance bacteria invasion of the interdental region by inducing relative ischaemia of this region. He also proposed that steroid might be an important nutritional factor for $P$. intermedia, thus, providing this organism with a selective nutrient advantage with subsequent overgrowth and increased inflammatory response. Studies by Shannon et al. ${ }^{63}$, Maupin and Bell ${ }^{64}$, and Cohen-Cole et al. ${ }^{65}$ further corroborated the possible role of cortisol the pathogenic mechanism of ANUG. Their study demonstrated an increase in the urine level of 17 hydrocycorticosteroids in ANUG patients when compared to the controls.

In addition, there is an associated increase in histamine concentration as a result of decreased dietary protein. This increase could be a result of decreased tissue retention of ascorbic acid which is important for the detoxification of histamine ${ }^{4}$ or as a result of increased pooling of histidine, an amino acid important for histamine synthesis. ${ }^{66}$ This increased histamine concentration results in hyperemia of the gingival due to increased capillary permeability and decreased PMN chemotaxis. ${ }^{67}$
Decreased dietary protein resulting from malnutrition also results in impairment of glycolytic activity, an activity which is required to give energy to PMN for phagocytosis. ${ }^{68}$ Also, energy required by the epithelial cells for rapid turn over every 3-6 days and by the periodontal collagen for metabolism and rapid remodeling is impaired. ${ }^{66}$

Ascorbic acid (Vitamin C), which is necessary for optimum phagocytic function of $\mathrm{PMNs}^{4}$ at a serum level of $0.7 \mathrm{mg} \%$, has been found to be extremely low in malnourished chidren. ${ }^{4}$ It has been found to be

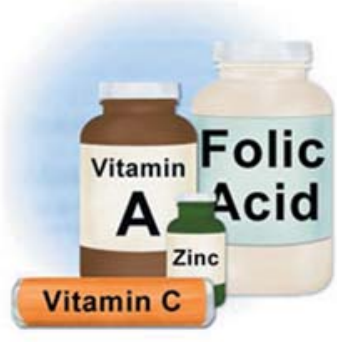
as low as $0.11 \mathrm{mg} \%$. $^{57}$

This results in impaired PMN function as well as increased histamine concentration.

Vitamin A has also been found deficient in these malnourished children, and this can cause progressive damage to mucosal tissues. ${ }^{7,57}$

Minerals such as zinc and folic acid have been found deficient in malnutrition. ${ }^{4}$ Folic acid is known to be important for the synthesis of purines, pyrimidines, and deoxyribonucleic acid and, thus, its deficiency adversely affects the integrity of the rapidly renewing epithelial cells.

In all, malnutrition does not only affect the integrity of the epithelium, which is the first defense barrier against infection, but also affects the number and depresses the protective function of the PMN against periodontal disease. This tends to be more severe in children.

Despite the widely understood possible mechanism of ANUG associated with malnutrition, not all malnourished individuals come down with ANUG. However, patients with ANUG and malnutrition also seen to have a past history of viral infection. The synergistic relationship between malnutrition and viral infections was implicated in the study by Enwonwu et $\mathrm{al}^{57}$. Viral infections such as that caused by human cytomegalovirus (HCMV), herpes simplex virus type 6 (HSV6) and EBV type 1 were implicated in their study. They noted that HCMV directly infects lymphocyes and monocytes thereby destroying the natural killer 
cells and causing decreased production of interleukin 1 and 2. HSV6 on the other hand inhibits various parameters of macrophage function ${ }^{57}$.

\section{The Role of Stress}

Other identified risk factors include stress. Stress could be in the form of emotional stress, which is often seen among military cadets $^{12}$, in harsh physical conditions, and in stressful living endemic contagious diseases, especially measles. Synergism between malnutrition and measles, a viral infection, has been reported to promote secondary infection by some resident oral microorganisms that ANUG spreads rapidly. ${ }^{7}$ Stress is believed to predispose to ANUG by causing an elevation in adrenocortical secretion. ${ }^{56}$ It also causes the release of substance $\mathrm{P}$, a peptide hormone which suppresses both specific and non specific immunity. It also affects patients' moods resulting in changes in oral hygiene and nutrition. ${ }^{68}$

\section{Oral Hygiene}

Another predisposing factor is poor oral hygiene, though questions arise to the relative contribution of poor oral hygiene to causation of this lesion. It has been observed that not all children with ANUG had particularly poor oral hygiene., 4,20,69 Schluger ${ }^{70}$ who described ANUG as a disease of 'filth' believes that a low standard of oral hygiene is the most single factor contributing to ANUG. However, he does not state the presence of the disease is always a result of lack of oral hygiene on the part of the patient but that plaque and debris accumulation occurs due to discomfort with oral hygiene practices. However, Mauphin and $\mathrm{Be}^{63}{ }^{63}$ found oral hygiene unrelated to ANUG.

Mentioned frequently in the literature is smokina as a predisposing factor to ANUG. ${ }^{11,4,64,71-75}$

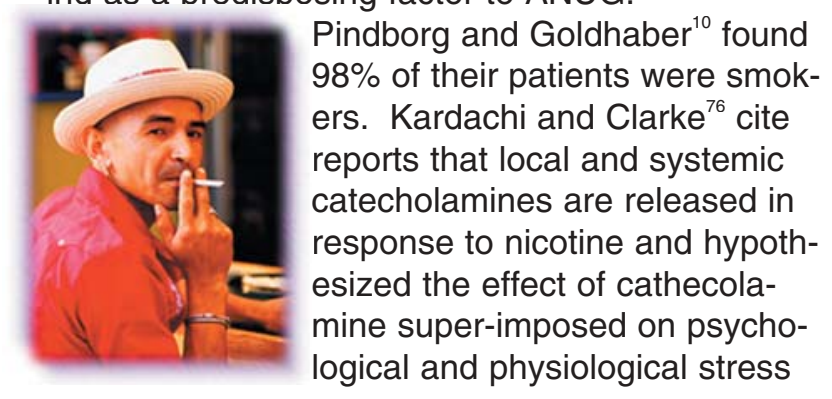

could cause a reduction in gingival papillary flow and, thus, cause papillary necrosis. Clarke et al. ${ }^{77}$ showed support for this hypothesis by demonstrating that intra-arterial infusion of epinephrine and nicotine in rabbits resulted in reduced gingival blood flow rates in spite of increased systemic pressure. This same hypothesis could hold true when there is an increase in the production of systemic cathecolamines in association with psychological stress.

Still another risk factor often reported is local trauma $^{70,78}$ Rizzo ${ }^{79}$ suggested the normal barrier created by the dentogingival unit requires ulceration before oral micro-organisms and their metabolites can penetrate. This is also pertinent if $F$. necrophorum is to be implicated as an important causative organism.

A number of ecological and behavioral variables which could intensify the risk of oral diseases in sub-Saharan African countries, of which Nigeria is one, has also been identified. ${ }^{81}$ These include poor food supply and preservation, reliance on inadequate and often heavily contaminated water supplies, close proximity of livestock to humans, earth floored resident units, and very poor disposal of human and animal feces. ${ }^{66,80,81}$ As a result of the Structural Adjustment Programme (SAP) in this region, the economic crisis has worsened with a resultant adverse effect on of the health and well-being of children, deteriorating sanitation, declining nutritional status, and increased exposure to infectious disease with malnutrition getting worse. ${ }^{82-85}$ Supplies of water are often obtained from polluted streams and shallow underground wells. Traditional weaning foods are usually heavily contaminated with fecal organisms. ${ }^{86}$ Thus, the most pressing health problems in this area, especially for those of the low socioeconomic strata, is malnutrition and infection. ${ }^{3}$

\section{Conclusion}

Modalities of treating ANUG over the years is almost as varied as its synonyms though they all center on reducing the bacteria flora. ${ }^{8}$ The use of antibiotics in the management of ANUG has been strongly advocated. ${ }^{1,13,88,89}$ Metrondazole has also been found to be as effective as penicillin in causing remission of the clinical symptoms, and this was parallel with reduction in the proportion of bacteria species associated with the disease. ${ }^{31}$ 
However, the highly preventable ANUG entails implementing measures aimed at eradicating malnutrition, improving oral hygiene status, and minimizing damage to oral mucosa as well as avoiding contamination of the oral environment by a heavy load of Bacteroidacease, particularly F. necrophorum. Oral mucosa ulcerations and traumatic lesions including traumatic tooth eruption should be considered to be potentially capable of evolving into ANUG. Also, the prevention of fecal contamination of water and weaning foods, improved nutritional status, and oral hygiene practices are other possible ways of preventing this highly preventable disease entity.

\section{References}

1. Emslie RD. Cancrum oris. Dental Practitioner and Dental Record 1963: 13:481-495.

2. Enwonwu CO. Nutritional disease in the tropics. In: Prabhu SR et al., (eds) Oral diseases in the tropics. Oxford University Press, 1992: 309-324.

3. Chandra RK. 1990 McCollum Award lecture. Nutrition and immunity: lessons from the past and new insights into the future. Am J Clin Nutr. 1991 May;53(5):1087-101. Review. No abstract available.

4. Enwonwu CO. Epidemiological and biochemical studies of necrotizing ulcerative gingivitis and noma (cancrum oris) in Nigerian children. Arch Oral Biol. 1972 Sep;17(9):1357-71. No abstract available.

5. Tempest MN. Cancrum oris. Br J Surg. 1966 Nov;53(11):949-69. No abstract available.

6. Pindborg JJ, Bhat M, Roed-Peterson B. Oral changes in South Indian children with severe protein deficiency. J Periodontol. 1967 May-Jun;38(3):218-21. No abstract available.

7. Enwonwu CO. Noma: a neglected scourge of children in sub-Saharan Africa. Bull World Health Organ. 1995;73(4):541-5. Review.

8. Cited by Printz H, Greenbaum SS. Diseases of the mouth and their treatment, Philadelphia; Lea and Febiger; 1935:153.

9. Hirchifield I, Beube F, Siegel E. The history of Vincent's infection. J Periodont. 1940; 11:89-95.

10. Pinborg JJ. Influence of service in armed forces on incidence of gingivitis. J Am Dent Assoc. 1951 May;42(5):517-22. No abstract available.

11. Goldhaber P, Giddon DB. Present concepts concerning the etiology of acute necrotising ulcerative gingivitis Int. Dent. J. 1964; 14:468-496.

12. Goldberg HJ. Acute necrotizing ulcerative gingivitis. J Oral Ther Pharmacol. 1966 May;2(6):451-9. No abstract available.

13. Melnick SL, Roseman JM, Engel D, et. al. Epidemiology of acute necrotizing ulcerative gingivitis. Epidemiol Rev. 1988;10:191-211. Review.

14. Williams DM. Classification and diagnostic criteria of oral lesions in HIV infection. J Oral Path Med. 1993: 22:289-291.

15. Pindborg JJ, Hostrup P. Necrotising gingivitis related to human immunodeficiency virus (HIV) infection. Afr Dent J. 1987; 1:5-8.

16. Porter SR, Luker J, Scully C, et. al. Orofacial manifestations of a group of British patients infected with HIV-1. J Oral Pathol Med. 1989 Jan;18(1):47-8.

17. Malberger E. Acute infectious oral necrosis among young children in the Gambia, West-Africa. J Periodontal Res. 1967;2(2):154-62. No abstract available.

18. Obiechinna AE. Cancrum oris: growing need to highlight a grave condition. African Health 1991; 13: 35-36.

19. Osuji OO. Necrotizing ulcerative gingivitis and cancrum oris (noma) in Ibadan, Nigeria. J Periodontol. 1990 Dec;61(12):769-72.

20. Taiwo JO. Oral hygiene status and necrotizing ulcerative gingivitis in Nigerian children. J Periodontol. 1993 Nov;64(11):1071-4.

21. Pindborg JJ, Bhat M, Devanath KR. Occurrence of acute necrotizing gingivitis in South Indian children. J Periodontol. 1966 Jan-Feb;37(1):14-9. No abstract available.

22. Smitt PA. Some clinical and epidemiological aspects of vincent's gingivitis. Dent Pract Dent Rec. 1965 Apr;15:281-6. No abstract available.

23. Pickhard HM. Historical aspects of Vincent's disease. Proc R Soc Med. 1973 Jul;66(7):695-8. No abstract available. 
24. Listgarten MA. Electron microscope observations on the bacterial flora of acute necrotizing ulcerative gingivitis. J Periodontol. 1965 Jul-Aug;36:328-39. No abstract available.

25. Listgaren MA, Socransky SS. Ultrastructural characteristics of a spirochete in the lesion of acute necrotizing ulcerative gingivostomatitis (Vincents infection). Arch Oral Biol. 1964 Jan-Feb;16:95-6. No abstract available.

26. Heylings RT. Electron microscopy of acute ulcerative gingivitis (Vincent's type). Demonstration of the fusospirochaetal complex of bacteria within pre-necrotic gingival epithelium. Br Dent J. 1967 Jan 17;122(2):51-6. No abstract available.

27. Courtois GJ 3rd, Cobb CM, Killoy WJ. Acute necrotizing ulcerative gingivitis. A transmission electron microscope study. J Periodontol. 1983 Nov;54(11):671-9.

28. MacDonald JB, Sutton RM, Knoll ML, et. al. The pathogenic components of an experimental fusospirochetal infection. J Infect Dis. 1956 Jan-Feb;98(1):15-20. No abstract available.

29. MacDonald JB, Gibbons RJ, Socransky SS. Bacterial mechanisms in periodontal disease. Ann N Y Acad Sci. 1960 Mar 29;85:467-78. No abstract available.

30. Hamp EG, Mergenhagen SE. Experimental infections with oral spirochetes. J Infect Dis. 1961 Aug;109:43-61. No abstract available.

31. Loesche WJ, Syed SA, Laughon BE, et. al. The bacteriology of acute necrotizing ulcerative gingivitis. J Periodontol. 1982 Apr;53(4):223-30.

32. Chung CP, Nisengard RJ, Slots J, et. al. Bacterial $1 \mathrm{gG}$ and $1 \mathrm{gm}$ antibody filters in acute necrotising ulcerative gingivitis. J. Periodontol. 1963; 54:557-560.

33. Wilton JM, Ivanyi L, Lehner T. Cell-mediated immunity and humoral antibodies in acute ulcerative gingivitis. J Periodontal Res. 1971;6(1):9-16. No abstract available.

34. Enwonwu CO, Falkler WA, Idigbe EO. Oro-facial gangrene (noma/cancrum oris): pathogenetic mechanisms. Crit Rev Oral Biol Med. 2000;11(2):159-71. Review.

35. Langworth BF. Fusobacterium necrophorum: its characteristics and role as an animal pathogen. Bacteriol Rev. 1977 Jun;41(2):373-90. Review. No abstract available.

36. Hofstad T. Current taxonomy of medically important nonsporing anaerobes. Rev Infect Dis. 1990 Jan-Feb;12 Suppl 2:S122-6. Review.

37. Falker WA Jr, Enwonwu CO, Idigbe EO. Microbiological understandings and mysteries of noma (cancrum oris). Oral Dis. 1999 Apr;5(2):150-5. Review.

38. Smith GR, Barton SA, Wallace LM. Further observations on enhancement of the infectivity of Fusobacterium necrophorum by other bacteria. Epidemiol Infect. 1991 Apr;106(2):305-10.

39. Buchanan W, Sehgal P, Bronson RT, et. al. Noma in a nonhuman primate. Oral Surg Oral Med Oral Pathol. 1981 Jul;52(1):19-22.

40. Smith GR, Turner A, Cinderey R. Susceptibility of wallabies to Fusobacterium necrophorum. Vet Rec. 1986 Jun 21;118(25):691-3.

41. Kaur M, Falkler WA Jr. Characterization of shared antigens of Fusobacterium nucleatum and Fusobacterium necrophorum. Oral Microbiol Immunol. 1992 Oct;7(5):291-8.

42. Adriaans B. Tropical ulcer-a reappraisal based on recent work. Trans R Soc Trop Med Hyg. 1988;82(2):185-9. Review.

43. Adriaans B, Drasar BS. The isolation of fusobacteria from tropical ulcers. Epidemiol Infect. 1987 Oct;99(2):361-72.

44. Cogen RB, Stevens AW Jr, Cohen-Cole S, et. al. Leukocyte function in the etiology of acute necrotizing ulcerative gingivitis. J Periodontol. 1983 Jul;54(7):402-7.

45. Rowland MG, Barrell RA, Whitehead RG. Bacterial contamination in traditional Gambian weaning foods. Lancet. 1978 Jan 21;1(8056):136-8.

46. Dennison DK, Smith B, Newkin JR. Immune responsiveness and ANUG. J. Dent. Res. 1985; 64:197.

47. Novak MJ. Necrotizing ulcerative periodontitis. Ann Periodontol. 1999 Dec;4(1):74-8. Review.

48. Scrimshaw NS, Taylor CE, Gordon JE. Interactions of nutrition and infection. Monogr Ser World Health Organ. 1968;57:3-329. Review. No abstract available.

49. Schultz-Haudt SD, From S. Dynamics of Periodontal tissues 1. The Epithelium. Odont. Ticlksr. 1961; 69:431-460. 
50. Carnerio, J. Synthesis and turnover of collagen in periodontal tissues in: the use of radioautography in investigating protein synthesis (edited by leBlond, C.P. and Warren. K.B.) New York: Academic Press; 1965:247.

51. Cutright DE, Bauer $\mathrm{H}$. Cell renewal in the oral mucosa and skin of the rat. I. Turnover time. Oral Surg Oral Med Oral Pathol. 1967 Feb;23(2):249-59. No abstract available.

52. Nelson RC, Jaffey H. Protein synthesis, microsomes, and polyribosomes in oral tissues. J Dent Res. 1969 Sep-Oct;48(5):857-62. No abstract available.

53. Topping NN, Fraser HF. Mouth lesions associated with dietary deficiencies in Monkeys. Publ. Hith. Reps. Wash. 1939; 54:416-431.

54. Platt BS, Stewart RJ. Experimental protein-calorie deficiency: histopathological changes in the endocrine glands of pigs. J Endocrinol. 1967 Jun;38(2):121-43. No abstract available.

55. Rao KSJ, Srikantia SG, Gopalain C. Plasma cortisol level in protein - calorie malnutrition. Arch Dis Childh. 1968; 43:210-213.

56. Alleyne GA, Young VH. Adrenocortical function in children with severe protein-calorie malnutrition. Clin Sci. 1967 Aug;33(1):189-200. No abstract available.

57. Enwonwu CO, Falkler WA Jr, Idigbe EO, et. al. Pathogenesis of cancrum oris (noma): confounding interactions of malnutrition with infection. Am J Trop Med Hyg. 1999 Feb;60(2):223-32.

58. Cornil A, Copinschi G, Leclercq R, et. al. Cortisol secretion during acute bacterial infections in man. Acta Endocrinol (Copenh). 1968 May;58(1):1-5. No abstract available.

59. Fisher LB, Maibach HI. The effect of corticosteroids on human epidermal mitotic activity. Arch Dermatol. 1971 Jan;103(1):39-44. No abstract available.

60. Gould BS. Collagen Biosynthesis, In: Treatise on collagen; Biology of Collagen (edited by Gould, B.S) New York: Academic press; 1968:139.

61. Dougherty TF, Berliner DL. The effects of hormones in Connective tissues cells. In: Treatise on collagen; Biology of collagen (edited by Gould, B.S.) New York: Academic Press; 1968:267.

62. Fauci AS. Mechanisms of corticosteroid action on lymphocyte subpopulations. I. Redistribution of circulating T and b lymphocytes to the bone marrow. Immunology. 1975 Apr;28(4):669-80.

63. Shannon IL, Kilgore WG, O'Leary TJ. Stres as a predisposing factor in necrotizing ulcerative gingivitis. J Periodontol. 1969 Apr;40(4):240-2. No abstract available.

64. Maupin CC, Bell WB. The relationship of 17-hydroxycorticosteroid to acute necrotizing ulcerative gingivitis. J Periodontol. 1975 Dec;46(12):721-2.

65. Cohen-Cole SA, Cogen RB, Stevens AW Jr., et. al. Psychiatric, psychosocial, and endocrine correlates of acute necrotizing ulcerative gingivitis (trench mouth): a preliminary report. Psychiatr Med. 1983 Jun;1(2):215-25. No abstract available.

66. Enwonwu CO. Infectious oral necrosis (cancrum oris) in Nigerian children: a review. Community Dent Oral Epidemiol. 1985 Jun;13(3):190-4. Review.

67. Ryan GB, Majno G. Acute inflammation. A review. Am J Pathol. 1977 Jan;86(1):183-276. Review. No abstract available.

68. Cainciola LJ, Genco RJ, Patters MR, et. al. Defective polymorphonuclear leukocyte function in a human periodontal disease. Nature. 1977 Feb 3;265(5593):445-7. No abstract available.

69. Jimenez M, Baer PN. Necrotizing ulcerative gingivitis in children: a 9 year clinical study. $J$ Periodontol. 1975 Dec;46(12):715-20.

70. Schluger S. The aetiology and treatment of Vincent's infection. J Am Dent Assoc 1943; 39:524.

71. Schwartz DM, Baumhammers A. Smoking and periodontal disease. Periodontal Abstr. 1972 Autumn;20(3):103-6. No abstract available.

72. Suzuki J, Falker Jr W, Parks S, et. al. Clinical and social profiles of ANUG patients in metropolitan area (Abstr. No. 773) J Dent Res. 1985; 64:261.

73. Pollman L, Dietrich A. [Acute necrotizing-ulcerative gingivitis in young men] Dtsch Zahnarztl Z. 1979 Feb;34(2):222-4. German.

74. Shields WD. Acute necrotizing ulcerative gingivitis. A study of some of the contributing factors and their validity in an Army population. J Periodontol. 1977 Jun;48(6):346-9.

75. Kowolik MJ, Nisbet T. Smoking and acute ulcerative gingivitis. A study of 100 patients. Br Dent J. 
1983 Apr 23;154(8):241-2. No abstract available.

76. Kardachi BJ, Clarke NG. Aetiology of acute necrotising ulcerative gingivitis: a hypothetical explanation. J Periodontol. 1974 Nov;45(11):830-2. Review. No abstract available.

77. Clarke NG, Shephard BC, Hirsch RS. The effects of intra-arterial epinephrine and nicotine on gingival circulation. Oral Surg Oral Med Oral Pathol. 1981 Dec;52(6):577-82.

78. Wilson JR. Etiology and diagnosis of bacterial gingivitis including Vincent's disease. J Am Dent Assoc. 1952 Jun;44(6):671-3. No abstract available.

79. Rizzo AA. Histologic and immunologic evaluation of antigen penetration into oral tissues after topical application. J Periodontol. 1970 Apr;41(4):210-3. No abstract available.

80. Etkin NL, Ross PJ. Food as medicine and medicine as food. An adaptive framework for the interpretation of plant utilization among the Hausa of Northern Nigeria. Soc Sci Med. 1982;16(17):1559-73. No abstract available.

81. Isely RB. Water supply and sanitation in African. World Health Forum 1985;6:213-219.

82. Sub-Saharan Africa: from crisis to sustainable growth. A long-term perspective study. Washington, D.C. World Bank, 1989.

83. Walker AF. The contribution of weaning foods to protein - Energy malnutrition. Nutr Res Rev. 1990; 3:27-47.

84. Berg A. Sliding toward nutrition malpractice: time to reconsider and redeploy. Am J Clin Nutr. 1993 Jan;57(1):3-7. No abstract available.

85. No Authors Listed. Structural adjustment and health in Africa. Lancet. 1990 Apr 14;335(8694):885-6. No abstract available.

86. Jelliffe DB. Infective gangrene of the mouth (cancrum oris). Pediatrics. 1952 May;9(5:1):544-50. No abstract available.

87. Johnson BD, Engel D. Acute necrotizing ulcerative gingivitis. A review of diagnosis, etiology and treatment. J Periodontol. 1986 Mar;57(3):141-50. Review.

88. Fitch HB, Bethart H, Alling CC, et. al. Acute necrotising ulcerative gingivitis. J Periodontol. 1963; 34: $422-425$

89. Horning GM. Necotizing gingivostomatitis: NUG to noma. Compend Contin Educ Dent. 1996 Oct;17(10):951-4, 956, 957-8 passim; quiz 964. Review.

\section{About the Author}

\section{M.O. Folayan, BChD, MBA, FWACS}

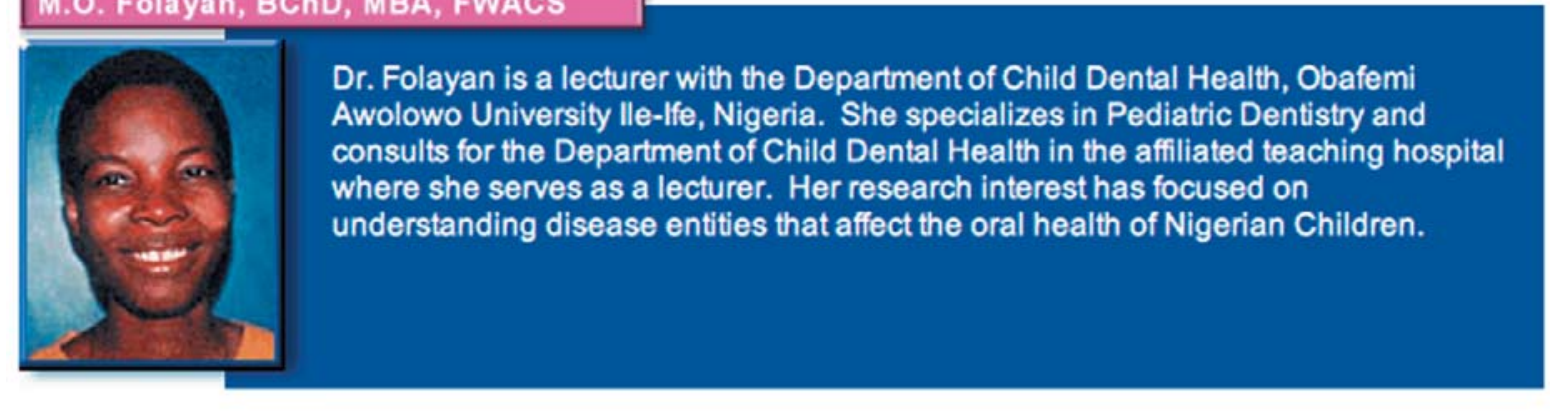

